\title{
European Journal of
}

\section{Philosophy, Culfure and Religious Studies}

\section{(EJPCR)}
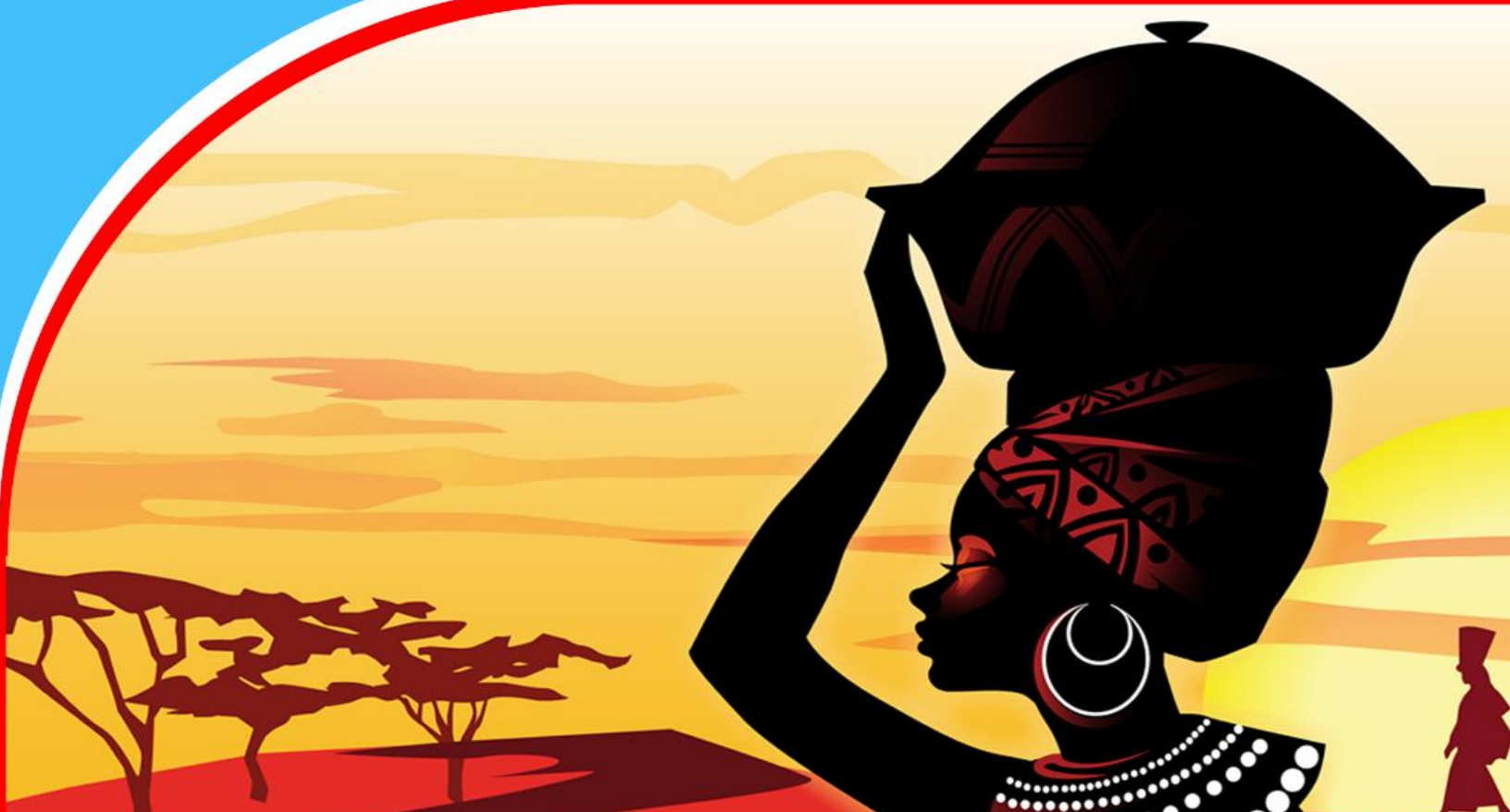

AGENTS IN THE PROCESS OF INCULTURATION: FRIEND OR FOE?

Okelloh Ogera

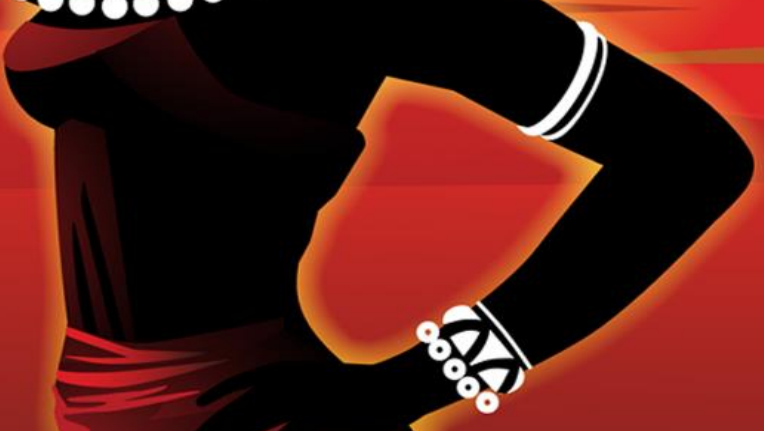




\title{
AGENTS IN THE PROCESS OF INCULTURATION: FRIEND OR FOE?
}

\author{
Okelloh Ogera \\ Catholic University of Eastern Africa \\ revokellohogera@gmail.com
}

\begin{abstract}
Purpose: This article looks at the role played by agents: the people responsible for articulating and implementing inculturation in Africa. The article asks the simple question of are these agents useful or a hindrance in the process of inculturation? The article begins by identifying these agents then discusses the challenges they face in the process of inculturation. The article concludes by giving a way forward and that is an integrated approach in inculturation.

Methodology: This study will review the available literature on the subject with a view to examining what previous research says concerning the role of the agents, that is human beings, in the process of inculturation. This was done with the main objective of examining the challenges that he agents of inculturation face, and concluding by exploring an integrated approach to inculturation, where all the agents are brought on board.

Findings: This study found out that if inculturation is to truly take root in African Christianity, it must bring on board all actors, not just Church leaders, and trained theologians, but also the laity. All these actors also need to overcome some of the challenges that have hindered the prospects of inculturation which include but not limited to fear of syncretism, lack of enthusiasm by some Church leaders, answering the question of culture in a post-modern and globalized world.

Unique Contribution to Theory, Practice and Policy: This paper will offer unique contributions to policies and practices governing the attempts to make the Church in Africa truly African by proposing a re-evaluation of the way inculturation has been carried out in the past. This has tended to be spearheaded by professional theologians and some church leaders, neglecting the biggest constituency in the entire process, and that is the consumer of inculturational processes; the laity.
\end{abstract}

Key words: Inculturation, African Christianity, Syncretism, Culture. 


\section{Introduction}

Christianity is by nature an incarnational religion. It never appears apart from a cultural web of language, symbols and practices. Sometimes the web is spun so tight that Christianity is identified with its host culture's good and bad aspects. In the case of Africa, this problem was exasperated by the fact that the culture that brought Christianity was also a culture which exerted tremendous power politically, socially and economically. For the African people, empowerment necessitated not only becoming a Christian, but adopting its European garb. However, this need not be the case, as Majawa (2005, p. 275) argues that no culture is foreign to Christ, and his message is not meant to bear the garb of any one particular culture or group. He goes on to say that the way one lives their fidelity to God, should not make one a foreigner in their own country. This paper aims at analyzing the role that the agents in the process of inculturating the message of Christ in Africa have played in either fulfilling or frustrating the inculturation. This paper also argues that the process of inculturation has not been all inclusive, thus stagnating inculturation. However, if the process were to be integrated and include all the agents, then the goals of inculturation could be realized much sooner. This is because in the process of inculturation in African Christianity, it seems that there is a neglect of one of the largest actors, the laity. The laity in African Christianity are regarded as people without an opinion and are merely meant to consume what the church leaders and professional theologians propose. It is the argument of this paper that the laity and indeed all other actors or agents come together in order for inculturational attempts to be successful.

\section{Meaning of Inculturation}

Inculturation according should be understood as the process whereby, the faith already embodied in one culture, encounters another culture (Magesa, 2004b, p. 17). In this encounter, the faith becomes part and parcel of the new culture. Waliggo (1986) explains further by saying that Inculturation means the honest and serious attempt to make Christ and his message of salvation evermore understood by peoples of every culture, locality and time. In other words, inculturation is the reformulation of Christian life and doctrine into the very thought patterns of each people.

Looking at the above definitions, one can't help but to notice that at the root of inculturation is the people. Inculturation, in the African context, should therefore be rightly thought of as a process or a movement which aims at making Christianity permanent in Africa, by making it a people's religion and a way of life which no enemy or hostility can ever achieve in supplanting or wakening (Waliggo, 13, 1997).

\section{Need and Urgency of Inculturation}

It is no secret that in the first centuries of Christianity, the Christian faith flourished in Roman North Africa, however, this church was mainly urban and Latin in orientation and did not permeate the entire populations of North Africa at the time, that is, the church remained mostly elitist (Waliggo, 1986, p. 12). With the onset of Islam in the seventh century, the seemingly established church in North Africa disappeared, save for few areas like Coptic speaking Egypt, and parts of 
European Journal of Philosophy, Culture and Religious Studies ISSN 2520-0445 (Online)

Vol.5, Issue 1, pp 1- 16, 2020

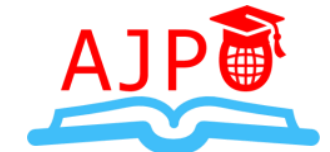

www.ajpojournals.org

Ethiopia and Nubia, where Christianity had been translated into the local languages, adapted into the local cultures and propagated by local evangelizers.

With the onset of the nineteenth and twentieth century missionary enterprise, Christianity has been established in Africa, particularly Africa south of the Sahara. This missionary enterprise was led mostly by Euro-American missionaries following evangelical revivals such as pietism and Methodism in Europe and the Great Awakening in the Americas. In the protestant circles, these movements led to the establishment of mission societies with the sole aim of evangelizing the new found lands of Africa and Asia. Roman Catholics also experienced a similar reawakening in this period following the founding of two missionary societies, namely the Congregation of the Holy Ghost Fathers (HGFs) and the Missionaries for Africa (MAfr) who were popularly known as the White fathers. The success of this missionary enterprise cannot be underrated despite the fact that it was also associated with slavery and colonialism.

Today, many African people have been converted to Christianity, and indeed, Christianity is growing, at least numerically, much faster in Africa than anywhere else in the World. However, the quality of this Christian faith has often been questioned. It is an often stated mantra that Christianity in Africa is many miles long but one inch deep. Many people argue that it is so easy for African Christians to revert to traditional practices and shun Christian practices, particularly when faced with a crisis in life. Laurenti Magesa (2004a, p. 91) calls this the instinctive behavior of the African people, explaining this by saying that people usually take instinctive personal or communal initiatives in addressing an issue at hand, and may tackle a problem in ways that may not be sanctioned by the Church, or even by the people concerned when they are themselves rationally confronted, despite the fact that they may profess to know and wish to act differently about the same issue. A good example is the case of polygamy which is not sanctioned by the church in Africa; however, for many African Christians who are in a monogamous relationship, and faced with the prospect of childlessness, would readily or instinctively opt for plural unions as the answer to this predicament. This might be an indication that Christianity has largely remained abstract, and has not been properly grounded in Africa. In other words, is Christianity feeling at home in Africa, or is it the stranger within?

If Christianity is not properly grounded in Africa, there is the fear that whatever happened in North Africa after the first seven centuries might repeat itself. Just as Waliggo (1986) cautions that there is no doubting that what has happened in the past, cannot happen again to the flourishing and numerically strong African Church today, arguing that, the durability of the Christian faith in Africa will not depend on its network of schools and parishes, hospitals, economic strength or even political support, but rather, the permanence of Christianity will stand or fall on the question whether it has become truly African. Pope John Paul II also sounded a similar warning, when addressing Mozambican Bishops in 1982. He said, "As long as the peoples of Africa do not feel Christianity as part of their own flesh and blood, their own soul, they will not be disposed to defend it." (Okure, 1990, p. 46). In other words, it is the task of the church to translate the gospel into forms suited to African culture, so as to make it well understood and even better lived by African people. 
This makes inculturation an urgent necessity within African Christianity. This is however not to say that nothing has happened to achieve inculturation in Africa, on the contrary, inculturation has been achieved to a certain extent, in the areas of liturgy as evidenced by the Zairean Roman Catholic liturgy of the Eucharist, and the inculturation of doctrines, especially the doctrine of Christ in theological writings of African theologians like Charles Nyamiti, John Pobee, Aylward Shorter among others. However, such successes of inculturation are few and far between. Even within the African Instituted Churches' (AICs), who seem to be practicing an inculturated Christianity, there is no theology consistent with practical pastoral behavior (Magesa, 2004b, p. 27). Some of these practical behaviors are also non-concomitant with the Gospel message. Magesa (2004) gives an example of the Akorino Church who accepts the powers of witchcraft and magic, even if they discourage their use.

\section{Process and Scope of Inculturation}

To understand the reasons for the stagnation of inculturation, one needs to look at the process and the scope of inculturation. Inculturation needs to be an ongoing dialogue between the Christian faith and African culture. The key word here is that the process needs to be an ongoing activity, partly because culture is dynamic, and partly because the goals of inculturation have not been fully realized. For the African Church not to experience the fears expressed by Waliggo (1994), the process of inculturation needs to be relooked at, with the sole aim of attempting to achieve the goals of inculturation.

Shorter (1988, p. 62), writing almost three decades ago was of the opinion that through inculturation, Jesus Christ adopts new approaches in carrying out his saving mission to the world, and the gospel acquires a new cultural language thereby enriching the church. He went on to opine that liturgy was meant to give a cultural expression to the people's faith, and the functions of the universal hierarchical structures of the church, while not being replaced, were to acquire new tasks in the dialogue with culture. Looking at the church in Africa today, one is left to wonder whether these positions or aims have been achieved. The African church needs to do a proper introspection to see if she is likely to achieve these goals of inculturation.

The gospel has been translated into a myriad of African languages, so one can argue that it has acquired a new, read African, cultural language. However, has Jesus Christ really adopted African approaches and ways in carrying out his saving work among Africans? Christ's saving work is meant to be holistic, that is, the whole person is saved; mind, body and soul. Listening to many sermons in many churches, particularly protestant, it seems Jesus Christ is only interested in saving the soul.

What about African liturgies, do they give cultural expressions to the faith of the African peoples? With the exception of some of the AIC's and a few Roman Catholic Dioceses like Zaire, most missionary church liturgies resemble the liturgies of their mother churches in Europe and America, liturgies that have historical origins in the Greco-Roman world. The same can be attributed to Church leadership. The universal and hierarchical structures of the church have not been 
European Journal of Philosophy, Culture and Religious Studies ISSN 2520-0445 (Online)

Vol.5, Issue 1, pp 1- 16, 2020

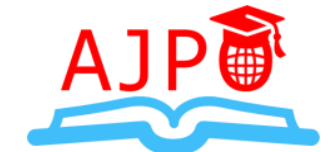

www.ajpojournals.org

transformed so that they can appeal to African leadership structures which are mostly based on eldership, nor to the ethos of African-hood which is communal.

The scope of inculturation has also to a large extent, been limited to liturgical rites and ceremonies, which have been adapted to local traditional cultures. One only needs to glance through some of the many writings on inculturation being produced by African theologians and Church leaders, and the reality downs that the focus is mostly on liturgical rites and ceremonies like the Eucharist, baptism, rites of passages, use of local melodies in Church music and Christian art inspired by local conceptions. Other than these, there are some doctrines which have been inculturated, for example, the doctrine of Christ. However, it is also important to note that the scope of inculturation needs to extend to totality of Christian life and doctrine (1986, n.d., p. 18). This is the only way that the goals of inculturation can be fully realized, and the Christian faith can have real meaning in the lives of Africans.

\section{Agents in the Inculturational Process}

One cannot talk about inculturation without talking about culture. Culture is a lived experience, a total way of life, not an on -off activity. Therefore in the process of inculturation, the message of Christ needs to become the total way of life of the African people. Just as Shorter (1987, 63), quoting Fr. Pedro Arrupe SJ as saying that in the process of inculturation, the Christian message needs to be incarnated into a particular cultural context such that this message finds expressions through elements proper to that particular culture, and becomes a principle that animates, directs, and unifies the culture, transforming it and remaking it and coming up with a 'new creation.' This new creation is the transformed culture, which is to be lived and experienced by the people.

Shorter was of the opinion that when evangelization is placed in the hands of the indigenous Christians themselves, then the process of inculturation is speeded up and the whole cultural system is enlivened from within. However, thirty years down the line and with evangelization firmly in the hands of indigenous Africans, inculturation has remained largely at the level of academic discourse, or at best, experimentation. In fact, some African Christians frown at the attempts to actualize inculturation simply because inculturation is seen as taking them back to "indigenous or traditional religious practices" which are, according to them, in direct conflict and competition with Christianity. This is the reason why the process of inculturation, the dialogue between faith and culture must incorporate all the agents.

It is important that the people, who are supposed to live and experience an inculturated faith, be part of the process, so that they can be part of the solution, not part of the problem. African Christians seem to be doing a lot in order to achieve the goals of inculturation as evidenced by the volumes of books, journal articles, and dissertations written on the subject. Some of these writings can be critiqued as to their true value or potential to the goal of inculturation, as Paul Gifford (2008) has done. Nevertheless it must be said that majority of these material remain to a greater extent, theoretical and not practical. Theoretical in the sense that they have very good proposals either on liturgy, doctrines, and sacraments, but do not essentially address the 'real' issues affecting African Christians like famine, negative ethnicity, hunger, calamities, diseases including the HIV/AIDS and Ebola epidemics, among others. This is however not to say that Africans cannot theologize in a practical manner, on the contrary, if some of the findings and messages of these 
European Journal of Philosophy, Culture and Religious Studies ISSN 2520-0445 (Online)

Vol.5, Issue 1, pp 1- 16, 2020

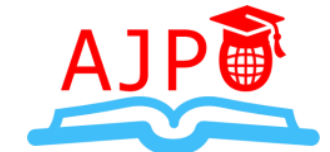

Www.ajpojournals.org

publications and dissertations were to be well articulated and implemented, then the process of evangelizing Africans in their own culture, while at the same time tackling the socio-political and economical issues would have been well underway.

Inculturation therefore seems to be an agenda restricted to the writings of African Theologians and not the masses. The laity seems to be disinterested in the theology of inculturation because it makes almost no reference to the traditional world-view of spiritual forces and spiritual causality. Of the African theologians, only Kalilombe (1999) insists that this is precisely the area inculturation must address, as ordinary people have little interest in the writings of the theologians since this worldview is ignored. Yet this world-view is significant because it forms the basic spirituality on which the very essential coping mechanism for life itself and its success depend. Such are for instance, the important areas of belief in medicines, magic practices and rituals which give assurance for dealing with the life problems of misfortune, sickness, natural disasters, and witchcraft - problems of failure or success in life, problems of death and survival. In other words, according to Kalilombe, as quoted in Gifford (2008);

People have been struggling with the Christian faith in as far as it proposes alternative basic beliefs in that area and critiques both the traditional ideas and convictions and the resultant practices and customs. Are the invisible powers to be understood alongside faith in Jesus Christ? Are people's fears, intentions and projects of solution to be guided by the new beliefs concerning the God revealed by Christ, the place and role of Jesus in his Paschal Mystery and the way of life proposed and shaped by such new beliefs? If the option was made in this sense, then the meaning of practices and customs of the people would be changed. Even the use of material and symbolic forms of the culture would take new shapes and that would point the way to a meaningful inculturation of the Christian faith.

This is the reason why, if inculturation is to achieve its intended goals, it needs every Christian to actively participate in its implementation, the religious leaders like Bishops, priests and pastors, theologians and the laity. These Christians are the agents in the process of inculturation.

An address by African Catholic Bishops in 1993 said, "The work of inculturation involves the entire Church community because it is the whole Church that must be missionary. Therefore it must never be thought that inculturation falls under the responsibility of foreign missionaries or of a handful of experts. It is the responsibility of the whole believing community. The drive for inculturation is therefore a movement with which everyone is associated." (XIV ORDINARY GENERAL ASSEMBLY, 1993, p. 43).

What the Catholic Bishops said at the time is important in the sense that they alluded to the folly of having the process of inculturation purely in the hands of theologians. McGarry (1995, p. $61)(1995,61)$ explains this by saying that if inculturation were the work of only experts, it might end up being a conceptual or technical inculturation coming from outside and not affecting people's lives. Inculturation needs to be able to have a positive effect on the lives of the people who experience the gospel message. Majawa (2005, p. 327) concurs when he says that the reasons for the failure of the recent inculturational efforts lies in the fact that decisions are made and directions given from above, and there is little or no participation from the common believers who 
European Journal of Philosophy, Culture and Religious Studies ISSN 2520-0445 (Online)

Vol.5, Issue 1, pp 1- 16, 2020

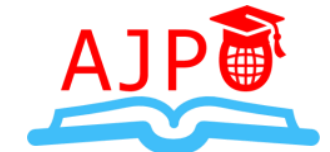

www.ajpojournals.org

encounter daily the realities of African life. Majawa (2005) concludes by warning that the inculturational process has not become a people's concern. Hence for true inculturation $t$ be realized, the process must be the concern of all the agents.

\section{Challenges Faced by Agents in the Process of Inculturation}

Inculturation seems to have stagnated at its infancy since there is no integrated approach to the process. The agents of inculturation do not seem to be reading from the same script. This is because; the attempts at inculturation have been disjointed, and at best unitarily undertaken. The reasons for these are numerous and in this paper, some of these reasons will be looked at.

\subsection{African Culture verses European Culture}

African people have abandoned or rejected their own culture and cultural practices and have embraced foreign cultures and practices. Culture can be defined as the complex whole which includes knowledge, belief, art, morals, law, custom, and any other capacities and habits acquired by human beings as members of a society. In other words, culture is a patterned way of life shared by a group of people. Before the arrival of European explorers, missionaries and colonialist, African people had their own cultural and religious heritage. Mission Christianity sustained an attack on the cultural and religious heritage that African's had.

For example, David Livingstone's concept of missionary enterprise differed from most of his colleagues among London Missionary Society (L.M.S.) missionaries. He saw mission centers not only for strictly evangelization purposes, but encompassing the whole spectrum of human activity. He divided this into three categories; commerce, Christianity, and civilization. It is not a secret that most missionaries though of African cultural and religious heritage as uncivilized. As Aylward Shorter (1987, p. 45.) notes, "African Traditional religion has been despised. Its adherents have been labeled pagan, heathen, idolatrous, polytheists, primitive, primal. Its beliefs and practices have been represented as an amorphous collection of customs and rituals." Sadly, the same state of affairs persists to the present day. Although there are indications that Africans initially rejected the supplanting of their own religious and cultural heritage with Euro-American culture, reality is they soon accepted the same due to many reasons, including colonization. This state of affairs has been eulogized in African literary writings such as Things Fall Apart by Chinua Achebe (1994) and The River Between by Ngugi wa Thiongo (1965).

Teresa Okure (1990, p. 58) also says that the reality of the European cultural forms through which the Christian faith was framed, expressed and transmitted to Africans, also needs to be recognized and accepted in all sincerity, for it is not possible to think of Christianity today in isolation from the Euro-American cultural forms, which have given it its shape, stamp and concepts such as sacraments, canon law and even morality. African converts to Christianity were therefore required to abandon their cultural heritage and adopt European cultures as a prerequisite to conversion. The height of this was being given a new "Christian" name during baptism or christening as a sign that one had been converted from "heathenism" or "paganism" to Christianity. Because of this assault on African culture, African people have lost their land and language, and by extension their 
European Journal of Philosophy, Culture and Religious Studies ISSN 2520-0445 (Online)

Vol.5, Issue 1, pp 1- 16, 2020

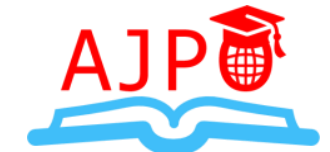

www.ajpojournals.org

identity. Majawa (2005, p. 281) warns that African people need to be deculturated, before any true inculturation can take place.

\subsection{Inferiority Complex}

The above scenario leads to the fact that there is a big distrust of anything considered Africa. African cultural heritage, as has been said has been under a sustained attack from other cultures and has for so long been branded heathen, negative, backward, pagan among other derogatory terms. Basil Moore, editor of a book Black Theology which was banned by the racist government of South Africa when it first appeared under the title Essays on Black Theology in 1972, could not have said it any better when he said that "the black people were made to believe not that salvation is in Christ alone, but that salvation is in accepting the new white ways of living. The effect of this was to internalize in the black people a sense of inferiority of the interchangeability, in religious language, of 'black' and 'evil' which according to him the black man was made to believe, were synonymous words, and it was therefore not difficult to persuade him that a black man was an evil (and inferior) person; and that his blackness is a sign of his inferiority as an outcast from the Grace of God." To this very day, Africans have an instinctive distrust for anything African, as these are viewed as inferior, but would readily welcome anything from Europe or America.

\subsection{Fear of Syncretism}

Syncretism can be defined as the amalgamation or attempted amalgamation of different religions, cultures, or schools of thought. This in most cases happens in the religious circles, when there is inter religious dialogue. Inculturation has been defined as a dialogue between the Christian faith and African cultures. However, one needs to realize that these two are not coming together as equals, on the contrary, Christianity is coming into the equation as superior since it is above all cultures, African culture included.

In Africa, syncretism can be found among some African Instituted Churches, which were founded as a consequence of resentment over missionary and colonial control, sometimes with dangerous effects. These churches try to reclaim some of the African traditional beliefs and practices which had been rejected by missionaries. These beliefs and practices are inserted into Christianity without any critical thinking, and are sometimes, placed side by side to the gospel and sometimes exalted above the Christian faith. A good example is when some of the founders of these Churches are elevated to the level of the messiah, Jesus Christ, or above the messiah, as has been seen in some Churches like the the Legio Maria Church of Kenya, The Church of Jesus Christ according to Prophet Simon Kimbangu in the Congo among others. Some of these Churches end up as cults or sects, and subvert orthodox Christian teachings and doctrines. Many Africans are afraid to fall into the same trap where orthodoxy and orthopraxy is thrown out of the window in the name of inculturation.

\subsection{Lack of Enthusiasm for Inculturation by African Church Leaders}

Religious leaders also seem to lack enthusiasm for inculturation. For many of them, inculturation is an academic endeavor that id discussed in the seminaries and theological colleges, and once one graduates and begins to practice ministry in a local church or a parish setting, all about 
European Journal of Philosophy, Culture and Religious Studies ISSN 2520-0445 (Online)

Vol.5, Issue 1, pp 1- 16, 2020

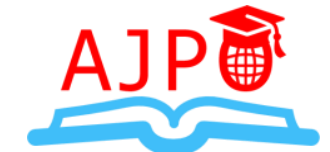

www.ajpojournals.org

inculturation is forgotten. As Shorter notes, "the Churches of the reformation were largely wedded to Western national cultures and traditions, and were not always able to overcome their ethnocentrism. Official Catholicism, on the other hand, clung to the moribund Latin culture of Western Christendom. The theoretical abandonment of this culture is too recent for it to cease operating immediately as a form of ecclesiastical subculture. This is perhaps a more insidious form of ethnocentrism, an ancient Western cultural tradition lodged in the ecclesial "woodwork" as it were.

The African leadership of these churches, therefore do not know any other forms of "being church" other than the ones handed down to them by the missionaries. So although the church in Africa has an African face, and body, its soul is still very much Euro-American. African church leaders would go to any level to protect the perceived form of Christianity inherited as the true form of Christianity and any attempts to dilute it with "African-ness" is met with strict opposition.

Part of the problem as to why African Church leaders do not have an enthusiasm for inculturation is the fact that most of them are deeply rooted in Western Lifestyles and thought patterns since they have been trained in Europe and America. As Joseph Galgalo (2012, p. 54) says, Africans are trained in and work with Western philosophical and theological categories, western hermeneutical and exegetical methods and these are alien to their African context. Although, Galgalo goes on to note that African theologians discard this Western methodological frameworks in their theology, seeking to grapple with models that can incarnate Christ in Africa in a way that is meaningful and practical. However, their impact at the Church in the grassroots is minimal, largely due to a disconnect between the theologians and the church leaders.

\subsection{Post-Modernism and Globalization}

Modernity has had a profound influence on the lifestyle and cultural values of African people. In many cases it was Christian missionaries who were the promoters of modernity, leading to an incipient connection between modernity and Christianity in the minds of the colonized and missionized. For many Africans "being Christian" and "being modern" or being "civilized" is one and the same thing. The recognition of this captivity by some indigenous Christians led to the development of African Instituted Churches as attempts to counter modernity with a renewed, "Africanized" understanding of Christianity.

With the onset of postmodernism and globalization, African people seem to be more "at home" in Euro-American culture. They speak and communicate in European languages, have EuroAmerican names, dress in European clothing, eating habits are influenced by Euro-American products like the soft drink Coke, Pizza among others. Generally speaking, African people have abandoned their own cultural heritage and adopted Euro-American cultures in the name of civilization.

Bernard Nyabweri and Michael Katola (2014) argue that cultural, moral and religious values in Kenya and other parts of Africa have been meddled with by the globalization phenomena, a condition which poses a solemn confront to the inculturation process. This is so because the Western mannerisms and religious philosophies which actually are a hindrance to inculturation are imported and socialized locally, criminalizing local cultures and religious performances. Nyabwari 
European Journal of Philosophy, Culture and Religious Studies ISSN 2520-0445 (Online)

Vol.5, Issue 1, pp 1- 16, 2020

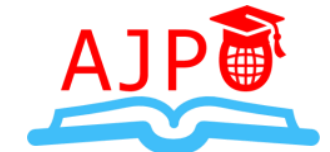

Www.ajpojournals.org

and Katola (2014) continue by saying that "Mimicked sermons and pulpit drama has undermined the inculturation process in Kenya. The language used, the songs done, the clothes worn by ministers, the sacraments and the liturgy are imitations of Western world. Preachers want to sound westernized as if they do not know their local language. They also ignore their local attire and continue wearing the Roman imperial attire that was adapted by the church during the Constantine era."

Local songs performed in the local language are perceived as boring and unspiritual by some ministers. The ministers ape cultures and preachers of the western milieu sacrificing their own Kenyan cultures. The fact that ministers and church members share knowledge, technologies, investments, resources and ethical values with other parts of the world, leads to people forgetting their own culture and values which would have been avenues to the success of the inculturation process.

\subsection{Denominationalism}

Jesus Christ founded one church in the World, however, when the European and American missionary came to Africa in the 19th century, they brought and planted a divided church. The roots of division have continued to grow even deeper in subsequent years. In spite of many and varied initiatives towards church unity, the African church scene is characterized by denominationalism and fragmentation. There are several reasons for these divisions; doctrinal, historical and ideological and theological. Even in the East African context, an attempt by Protestant missionaries at the formation of a united Church failed. Samuel Kobia (2001) argues that, "The fears of non-episcopal churches also had a strong bearing on the decision not to pursue the idea of a united church. The representative of the American Inland Mission (AIM), Mr Hurlbert, made a strong statement in which he reiterated "the integrity of scripture and the deity of our Lord" as being above any tradition. Given the relentless view of the Church of England, and his own view which was supported by some other non-episcopal churches, he concluded that a united church could only be based on compromise and that would hinder any real fellowship."

With this in mind, Churches in Africa are averse to cooperation. It is highly unlikely that the different Churches in Africa can come together in an effort to have a united agenda on inculturation. Every denomination is left to treat the subject of inculturation at their own level. It is important to note that these different denominations serve the same people in the areas in which they are active. However, completion for members has so blinded the different denominations such that the scandal of a divided Church continues unabated. The different denominations would rather discuss on a common table, social issues affecting the populace such as the HIV/AIDs pandemic, but not anything theological or doctrinal. One is left to wonder if the message of the Gospel is meant to divide rather than unite. Kobia (2001) sums it well when he says "the ecumenical sharing of resources for development led to the popular dictum, "doctrine divides, service unites."

\subsection{Potency of Christianity}

As has been said, Christianity in Africa seems to be many miles long but only one inch deep. In supporting this assertion, Gideon Para-Mallam (2008) argues that the impact of the gospel on 
European Journal of Philosophy, Culture and Religious Studies

ISSN 2520-0445 (Online)

Vol.5, Issue 1, pp 1- 16, 2020

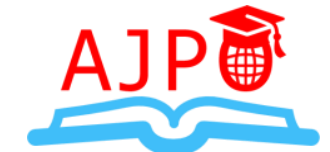

www.ajpojournals.org

society is diminished by the disjuncture of belief and practice. One major result of the disjuncture between belief and practice is the lack of depth found in many Christians. Religiosity is widespread; however, godliness is scarce. People from all walks of life profess faith in God; yet this is not displayed in everyday life practices. Reasons for this could be attributed rightly or wrongly to Christian dualism. Christian dualism can be summed up as anthropological, where man is composed of two parts, a body and a soul; and metaphysical, where the heaven is treated as more important than the earth. This dualistic nature has tended to portray Christianity as abstract, focusing only on the person's soul and not the person in totality, as was the case with most African Traditional Religions (ATR), where the body and the soul were of great significance. Hence, Christianity, at least for the African people, does not seem to provide real solutions to real problems such as sicknesses, witchcraft, natural calamities among others. In ATR, if one sinned or broke the moral codes, justice was swift and punishment was immediate, unlike in Christianity where people have to wait until the eschaton for God to judge everyone. There is no more fear of the sacred; after all Christianity does not seem to have the potency of ATR. In ATR, one would not break an oath, but in Christianity, people break their vows openly and wantonly, subverting the Christian faith and practices. This is the instinctive behavior that Magesa (2004) has so eloquently explained. This begs the question, "Is religion in Africa an outside ritualistic expression without requisite morality and spirituality?" (Mwaura, 2007).

\section{Towards an Integrated Approach to Inculturation}

Clement Majawa (2005) has tackled the issue of an integrated approach to inculturation in his book Integrated Approach to African Christian Theology of Inculturation. In this book, Majawa explores the theory, practice and guidance in the process of inculturation, which according to him, should involve all people of God. In chapters fifteen and seventeen of his book, he lays the framework for incorporating the laity in the process of inculturation. It is however important to point out that Majawa writes primarily from the Roman Catholic perspective.

Majawa (2005, p. 68) says that the modalities of inculturation in Africa need to employ the method of systematic reflection of African cultural values, in the light of the Christian faith. In this method, there are four levels which are, firstly; identification of pastoral, theological, moral, spiritual or doctrinal problems within the African local churches. Secondly; systematic and comparative exposition of the cultural data and the Christian faith so that pots of departure and convergence can be identified. Thirdly; purification of the positive cultural elements by relating them to the scriptures, church traditions and the Magisterium; the teaching authority of the Church. Lastly; the functional approach and pastoral praxis, where the inculturated theology or doctrine is implemented or applied in a local church.

Looking at Majawa's (2005) modalities for inculturation, clearly it is an integrated approach where all the agents in the process of inculturation have a role to play. The laity, the religious leaders like priests and pastors, members of the religious orders, as well as theologians can come together to identify the problem or issue as mentioned in level one. Levels two and three can effectively be 
European Journal of Philosophy, Culture and Religious Studies ISSN 2520-0445 (Online)

Vol.5, Issue 1, pp 1- 16, 2020

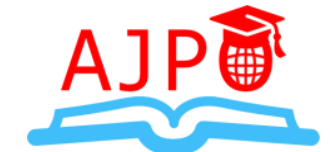

www.ajpojournals.org

tackled by the theologians and religious leaders, and before implementation in level four, let all the Christians come together again to articulate, discuss and either accept or reject practice of the inculturated doctrine, theology or pastoral issue.

For the goals of inculturation to be fully realized and achieved in Africa, Africans need to realize the fundamental fact that the context of Christianity in Africa is replete with numerous denominations and churches. Therefore, the agents of inculturation need to be able to explore the theories and the practice of inculturation from an intra-denominational perspective, as Majawa (2005) has done, but also from an interdenominational perspective. After all, the message of Christ, the content of inculturation, is the same, and it is meant to be lived and experienced by African people irrespective of their ecclesiastical background. Even as this is done, people need to be aware of the different denominational doctrines that so easily divide.

\subsection{Intra-denominational Approach}

Many churches in Africa are already attempting to inculturate their doctrines, liturgies and other aspects of Christianity within the African continent. The problem is that these attempts are few and far between and are mostly based within particular denominations and in particular places or contexts. Therefore, their efforts, as good as they may be, are not visible to other Africans who may be facing a similar challenge or trying out a similar process. Unless a theological student who is interested in such inculturational activities picks it up and writes a thesis or dissertation on it, the process may virtually pass unnoticed.

Some of these Churches have adopted inculturation as official church policy, pointing to the reason some denominations seem to be head and shoulder above others in inculturating Christianity in Africa. The Roman Catholic Church for example appears to be miles ahead in inculturation, as the process has been adopted officially as an ecclesiastical policy stemming from the highest authority on ecclesiastical matters within Roman Catholicism, the Pontiff. This is illustrated in the numerous pontifical exhortations on Inculturation, particularly after the second Vatican Council. Such exhortations include Africae Terrarum which was a message of Pope Paul IV to Africa in 1967, Pope Paul VI address to African Bishops in Kampala Uganda in 1969, Pope John Paul II's address to Zairean Bishops in 1983, Pope John Paul II's address at the opening of Catholic University of Eastern Africa in Nairobi, 1985 among others. However, even with all these seemingly official support, there seems to be little, if any official reflection of inculturation by any church. That is, no Church has come with their own official policy on matters inculturation. It is a sad state of affairs that other churches do not see the need of inculturation.

Many different churches already have systems, policies and practices in place that can be used to further the inculturational process, particularly a process that incorporates all the agents. It is important that the different denominations or churches have intra-denominational modalities for inculturation as they will not be bogged down by doctrinal differences, which can be witnessed in ecumenical circles. Some practical examples where churches can have or allow all God's people to dialogue about the objectives, the process and the goals of inculturation are discussed next. It is 
European Journal of Philosophy, Culture and Religious Studies ISSN 2520-0445 (Online)

Vol.5, Issue 1, pp 1- 16, 2020

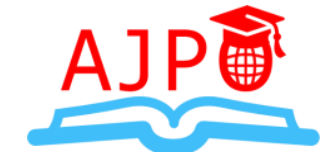

Www.ajpojournals.org

important to note that these practical examples bear in mind the fact that inculturation is a dialogical process, and for dialogue to succeed, everybody needs to be on board. Everybody needs to be aware of the need and urgency of inculturation if it is to succeed.

\subsection{Small Christian Communities}

Majawa (2005, p. 325) describes the Small Christian Communities (SCCs) as groups of believers in Jesus Christ and his teachings, wherein there is an intense life of faith, mutual acceptance, understanding, love, community proclamation of the word of God, sharing of the faith experiences, and celebration of the sacraments. The SCCs exist in different forms and are known by different terminologies within African Christianity. The terminology of SCCs is synonymous with Roman Catholicism; however, the reality of SCCs can be witnessed in virtually all the churches operating within Africa. Within other Christian circles, the SCCs are known as Small Church Groups, Mtaa (Area or Estate) fellowships, Cell groups, Clusters, Bible Study Groups, among a coterie of other names.

It is important to note that not all SCCs are the same; uniqueness and differences will often emerge based on the different contexts within Africa. However, the SCCs are important as Majawa (2005,p. 326) says, Africans are generally community oriented and are more accommodating in their philosophy, spirituality and communal or social life. Although SCCs are predominantly denominational, during SCC gatherings, the people will more often than not, invite their neighbors who belong to other denominations to attend, particularly if a priest or pastor is present to celebrate a certain sacrament. Therefore the SCCs can also be used in ecumenical circles to dialogue about inculturation.

Majawa (2005, 327-330) lists several reasons as to why the SCCs are the ideal place for inculturation in Africa. For a comprehensive understanding of these reasons, one needs to read Majawa's book. A few of these reasons will however be highlighted here. They include the fact that the membership of the SCCs accept, reflect on, assimilate and live the incarnate word in their actual cultures. The SCCs also have the potential to incarnate the universal church in a particular local culture. The SCCs are a means to institutional renewal, as well as restructuring ministries within the church in keeping with the image of the church as a community. This resonates very well with the African Inculturated doctrine of the Church as a community. SCCs are also places, as has been said for ecumenical encounter and dialogue as well as places for experimentation. It is in such communities that new liturgies, symbols, prayers among others can be experimented before being presented to the wider Christian Community. For more discussions on the role of the SCCs, see Joseph Healey's (2009) article.

\subsection{Catechism}

Catechisms are doctrinal manuals often in the form of questions followed by answers to be memorized by new converts or preparation for sacraments. Catechism can also be defined as a summary or exposition of doctrine used primarily as an introductory teaching to the Christian 
doctrines, sacraments and practice. Different denominations have different styles and manner of conducting their catechism. Since catechism is a form of instruction on matters of doctrine and faith to the lay people, it can also be a rich ground for inculturation. As Majawa (2005) notes, lay people are the main possessors of popular religious sense, they are in a better position to judge what is inadequate, obsolete or unsuitable, and hence the faith can be taught in a form that is truly vital to the people. Majawa (2005) concludes by warning that inculturation in catechesis is not a simple adaptation of an old catechetical instruction with new terms and pedagogic techniques nor ethnocentricism, it is the penetration of faith to the profound levels of human life, influencing the manner of human thinking, feeling and acting.

\subsection{Lay Training}

African Christianity cannot run away from the fact that it depends largely on lay ministry. Lay ministry is a term used for members of faiths and Christian denominations who are not full-time paid clergy, or not ordained clergy, but who perform the same or similar function as those of a priest within a local church. Particularly within the protestant circles, who believe in the priesthood of all believers, all Christian people are seen to have a calling from God to know and love him more, and to serve others in his name. These Churches have elaborate training for the lay ministers in order to equip them in the service of God among their people. This training is also useful in equipping one in faith and ministry development, in order to fulfill their calling to Christian discipleship and mission. The training regimes vary from church to church and include Theological Education by Extension (TEE), Short Courses, or even long term professional courses at either certificate or diploma level. Through such training of lay ministers, the agenda of inculturation can be introduced and discussed at that level.

\subsection{Post Ordination Training, Conferences and Synods}

Many of the churches that do train their clergy and priests in formal seminaries and theological colleges do not have a standard strategy for post ordination training. Rarely does one hear that a church has organized even conferences and seminars where their ministers and clergy can come together with other church leaders and theologians to discuss issues affecting the church in general and inculturation specifically. Other places where inculturation can be discussed is in church synods and governing councils. A synod is a council of a church, usually convened to decide an issue of doctrine, administration or application. In modern usage, the word often refers to the governing body of a particular church, whether its members are meeting or not. It is also sometimes used to refer to a church that is governed by a synod. Since synods determine issues of doctrine, administration or application, what better place then to discuss and agree on the issue of inculturation. In some churches like the Anglican Church, membership of the synod is composed of both the clergy and the laity. This makes the synod suitable for such deliberations on how people are to live and practice their faith. 
European Journal of Philosophy, Culture and Religious Studies ISSN 2520-0445 (Online)

Vol.5, Issue 1, pp 1- 16, 2020

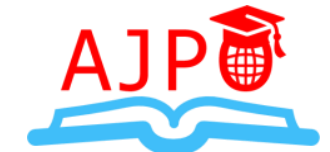

www.ajpojournals.org

\subsection{Inter-Denominational Approaches}

Interdenominational approaches towards the process of inculturation are meant to be rightly ecumenical as well. Africa has lots of ecumenical theological associations that are capable of discussing issues relating to the theory and practice of inculturation. Such associations include the Circle of Concerned African Women Theologians, Ecumenical Association of Third World Theologians, Ecumenical Symposium of East African Theologians (ESEAT), and Association of Theological Institutions in East Africa (ATIEA) among others. Some of these theological associations publish journals where papers on the process and practice on inculturation can be disseminated and shared with similar contexts within Africa to learn.

The different denominations within Africa can also use the ecclesiastical associations such as the national, regional or continental associations of churches to further the aims of inculturation. Such bodies as the All Africa Conference of Churches (AACC), the national Christian Councils like the National Council of Churches of Kenya (NCCK) or regional bodies like the fellowships of Christian Councils and Churches in the Great Lakes and Horn of Africa can also be used to achieve the goals of inculturation. Although such bodies as has been mentioned are primarily protestant, it is important to note that they provide a starting point of inter church cooperation. Already existing networks and links of such Christian organizations can provide the springboard for dialogue on inculturation. Such organizations have had a fairly great success when it comes to solving some of the social problems affecting Africans, with successes coming in the areas of HIV/AIDs, peace building and conflict transformation, human rights advocacy, capacity building and so on. Hopefully, such successes can be replicated in the area of inculturation when the different churches come together under a common goal.

\section{Conclusion and Recommendations}

This paper, sought to answer two main questions: Firstly; what are the challenges that the agents in the process of inculturation face? Secondly; how can these challenges be mitigated? This paper also argues that for the goals of inculturation to be fully realized, the process must of necessity and urgently incorporate all the agents, and the dialogue needs to be both intra-denominational as well as inter-denominational. Africans must also ask the critical question of what is the face of contemporary African culture. This paper recommends that more research needs to be done on methodologies that can integrate the laity in any attempts at inculturation. The paper also recommends that when it comes to African culture and the process of inculturation, care needs to be taken as culture is not static but dynamic. In contemporary Africa, one might wonder what really African culture refers to, as current African culture has borrowed a lot from Euro-American and post-modern cultures. Indeed, there are many Africa people who were born just at the dawn of the millennium, who might not associate with traditional cultures of African people. 
European Journal of Philosophy, Culture and Religious Studies

ISSN 2520-0445 (Online)

Vol.5, Issue 1, pp 1- 16, 2020

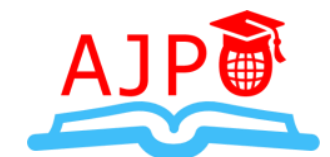

www.ajpojournals.org

\section{References}

Achebe, C. (1994). Things Fall Apart. Penguin Books.

Galgalo, J. (2012). African Christianity: The Stranger Within. Zapf Chancery Research Consultants and Publishers.

Gifford, P. (2008). Africa's Inculturational Theology: Observations of an Outsider. Hekima Reveiew, 38, $18-34$.

Healy, J., G. (2009, September 15). The Role of the Small Christian Communities (SCCs) in the Implementation of Reconciliation, Justice and Peace in Africa. AMECEA Consultations on the Second African Synod, Nairobi, Kenya.

Kalilombe, P. (1999). Doing Theology at the Grassroots: Theological essays from Malawi. Mambo Press.

Kobia, S. (2001). Denominationalism in Africa: The Pitfalls of Institutional Ecumenism. Ecumenical Review, 53(3), 295-305.

Magesa, L. (2004a). Anatomy of Inculturation: Transforming the Church in Africa. Orbis Books.

Majawa, C. (2005). Integrated Approach to African Christian Theology of Inculturation. Creations Enterprises.

McGarry, S. J. (Ed.). (1995). What Happened at the African Synod. Paulines Publications Africa.

Mwaura, P. N. (2007). Integrity of Missions in the Light of the Gospel: Bearing Witness of the Spirit among Africa's Gospel Bearers. Mission Studies, 24(2), 189212.

Nyabwari, B., \& Katola, M. T. (2014). Constraints and prospects of Inculturation in Kenya. Iternational Journal of Academic Research in Business and Social Sciences, 4(2), 282-290.

Okure, T. (1990). Inculturation of Christianity in Africa. AMECEA Gaba Publications.

Para-Mallam, G. (2008). Theological Trends in Africa: Implications for Missions and Evangelism. Lousane World Pulse.

Shorter, A. (1988). Toward a theology of inculturation. Orbis Books.

Thiong'o, N. wa. (1965). The river between. Heinemann.

Waliggo, J. M. (1986). Inculturation: Its meaning and urgency. St. Paul Publications.

XIV ORDINARY GENERAL ASSEMBLY. (1993). Instrumentum Laboris - The Vocation and the Mission of the Family in the Church and in the Contemporary World. http://www.vatican.va/roman_curia/synod/documents/rc_synod_doc_20150623_instrumentumxiv-assembly_en.html 